\title{
Discurso de abertura XXX Simpósio Brasileiro de Política e Administração da Educação
}

ROMUALDO PORTELA DE OLIVEIRA

Presidente da ANPAE

Professoras,

Rinalva Cassiano Silva, Maria Beatriz Moreira Luce, Marcia Ângela da Silva Aguiar, e professor João Ferreira de Oliveira, ex-presidentes da Anpae.

Senhoras e Senhores, professoras e professores, representantes das entidades coirmãs que gentilmente nos enviaram sua saudação e com quem compartilhamos as lutas e sonhos por uma educação de qualidade para todos e um país mais justo e humano;

Senhoras Professoras Andreia Ferreira da Silva, vice-presidente do Nordeste, Ney Cristina de Oliveira, vice-presidente do Norte, Carina Elisabeth Maciel, vice-presidente do Centro Oeste, Gisele Masson, vice-presidente do Sul, senhor professor Itamar Mendes da Silva, vice-presidente do Sudeste;

Senhora professora Maria Couto Cunha, do Conselho Fiscal, Senhor professor Erasto Fortes de Mendonça membros do Conselho Fiscal e In Memorian professor Cleiton de Oliveira;

Senhoras e senhores professores membros da diretoria, senhoras e senhores professores diretores e coordenadores estaduais da Anpae,

É com imensa alegria que dou início ao XXX Simpósio Brasileiro de Política e Administração da Educação, comemorativo dos 60 anos da Anpae.

Quero iniciar marcando essa sessão como um ato de alegria, um ato de fé no futuro e, ao mesmo tempo, de respeito por nossa história. Por isso, lembro de centenário do homenageado deste ano, Patrono da Educação Brasileira, que diz: "É preciso ter esperança, mas ter esperança do verbo esperançar; porque tem gente que tem esperança do verbo esperar. E esperança do verbo esperar não é esperança, é espera. Esperançar é se levantar, esperançar é ir atrás, esperançar é construir, esperançar é não desistir! Esperançar é levar adiante, esperançar é juntar-se com outros para fazer de outro modo..."

Somos uma associação esperançosa, no sentido freireano do termo. Muitos dos que aqui estão sabem o quanto lutamos para construir uma Anpae alinhada com a defesa da educação pública, democrática, laica e de qualidade para todos, que se integra nas lutas democráticas da sociedade brasileira, sabendo que 
o futuro sempre é incerto e depende, em grande parte, de nossa ação hoje. Mas nós sabemos o quanto a sociedade brasileira lutou por mais democracia, e, ao valorá-la, sabemos o que está em jogo neste momento crucial de nossa história. Por isso, por mais difícil que seja o presente, cá estamos nós para seguir o poeta e afirmar que "amanhã será outro dia", e todos os horrores que presenciamos vão passar.

Vão passar com a esperança freireana de nossa ação, de nossos parceiros do FNPE, da construção conjunta e democrática de uma Conape que represente a organização da sociedade civil e contribua para refletirmos sobre o futuro da educação nacional. Juntos estaremos em Natal, em julho do próximo ano, avaliando o atual plano nacional de educação e nos preparando para os embates em torno do próximo. De agora até lá, estaremos avaliando os acertos e os erros cometidos em nossa trajetória, para estarmos mais preparados para as disputas futuras.

Este também é um momento de festa, e este simpósio foi pensado como um momento de reflexão que começa com uma festa de aniversário, da Anpae, e termina com outra festa de aniversário, do centenário de Paulo Freire, entremeada com reflexões que nos qualificam para a luta que está adiante.

Chegamos aos 60 anos maiores e mais organizados que nunca. Hoje temos seções em 24 estados e no Distrito Federal. Esperamos até o final desta gestão nos organizarmos em todas as unidades da federação. Vontade não nos falta.

Neste último período, desde a última vez que nos reunimos, em Curitiba, em 2019, ampliamos nosso quadro associativo, lançamos a revista Educação básica em foco, fortalecemos a RBPAE e a editora ANPAE.

A Revista Educação Básica em Foco é um símbolo de um novo momento da Anpae, que procura ampliar sua relação e inserção na educação básica. Neste momento, não poderia deixar de cumprimentar as professoras Maria Angelica Minhoto, Emilia Peixoto Vieira, Dalva Valente que estão à frente desse projeto e a professora Maria Vieira da Silva que esteve com o grupo nos primeiros números da revista. Esta publicação pretende ser nosso instrumento de diálogo com a educação básica, de reflexão e articulação da universidade e da escola básica. Mas ela é apenas o primeiro movimento que fazemos no sentido de ampliar nossa interlocução com a escola básica. Em breve, pretendemos lançar os cursos formativos da Anpae, para disputar concepções de gestão da educação, fortalecendo a perspectiva da gestão democrática da educação. Queremos refletir sobre a educação básica com os sujeitos da educação básica, seus gestores e seus 
professores. Aos que aqui já estão, recebam nossas boas-vindas. A Anpae é, e pretende ser cada vez mais, também uma entidade de profissionais da educação básica.

Defendemos a gestão democrática, não apenas porque a educação ou é democrática ou não é educação, uma escola democrática pressupõe uma sociedade democrática, mas, também, uma sociedade democrática pressupõe uma escola democrática.

E democrática deve ser a escola não apenas no sentido de uma escola para todos, em que a educação não seja um privilégio, mas um direito, na qual não tenhamos excluídos da escola, e a pandemia nos lança o imenso desafio de não diminuirmos o acesso, de combatermos a exclusão que as faltas de condições para o ensino remoto ou híbrido e a pobreza geram no acesso à escola.

Mas além de lutar contra a exclusão da escola, temos de lutar contra a exclusão na escola. Não podemos ser coniventes com os processos escolares que reprovam e depois excluem os mais pobres, os negros, os indígenas, os meninos. Dessa forma, os indicadores de reprovação, abandono e defasagem série/idade, indicam processos de exclusão no interior da escola que devem ser combatidos em nome do direito de todos à educação.

Finalmente, defendemos uma escola em que todos tenham o direito de aprender. Todos têm o direito de ir à escola, lá permanecerem, serem bem tratados, respeitando-se suas características; e todos têm o direito de aprender a ler o mundo, têm o direito de ter acesso ao saber historicamente construído.

Mas para nós, a escola democrática não apenas garante o acesso, a permanência, o adequado tratamento e o aprendizado para todos, mas também é gerida democraticamente, tanto no nível de unidade escolar como no nível de sistema.

E nós defendemos a democracia também na gestão porque ela é eficiente. Não compartilhamos da ilusão de burocratas encastelados em secretarias de educação e ministérios que acham que assinando um decreto, na simples canetada, mudam a educação. Sabemos que apenas o debate franco e democrático é capaz de fazer a escola se mover, caso contrário ela não se move, tornando-se arraigado espaço de resistência. É o que vemos Brasil afora. Sem democracia não se muda a escola. E a prova disso é a experiência vivida em muitos lugares desde a redemocratização e a aprovação da Constituição de 1988. Quando não há democracia na educação, ela não muda. Ainda que se faça o discurso de eficiência da gestão. Ela é ilusória se não engajar a comunidade escolar. 
Da mesma forma, não existe política educacional eficiente que não seja democrática. Apenas com a participação da comunidade escolar nas definições das grandes linhas da educação é que poderemos mudar a educação neste país.

Assim, se este evento comemora e rememora o passado, e temos muito a comemorar, também é um evento que prepara o futuro. E temos muito para o que nos preparar. Assim como este aniversário renova nossos laços de solidariedade, do fazer juntos, renova nossa disposição de seguir adiante.

É por isso que nos engajamos na articulação com outras entidades para fortalecer a ação conjunta e a participação popular na definição das políticas e na gestão da educação.

E por entendermos a importância estratégica da educação na construção de uma nova sociedade, no conhecimento como motor da economia do século XXI, que para nós é indissociável o investimento em educação do investimento na pesquisa e na ciência e tecnologia. Só assim, teremos condições de superar a triste posição de exportador de produtos primários e, portanto, gerador de pobreza e desigualdade.

Por isso, para nós, lutar por uma sociedade mais justa pressupõe revogar a EC 95 e defender mais verbas para a educação e para a pesquisa científica. Assim, realizamos esse simpósio. Com festa e poesia e como reflexão preparatória para ação.

Vida longa à Anpae. Bom simpósio a todos. 